\title{
PSYCHROPHILIC METHYLOTROPHIC BACTERIA IN ANTARCTIC REGION BIOTOPES
}

\author{
V.A. Romanovskaya, D-r Biol. Sci., P.V. Rokitko, Ph. D. Biol. Sci., \\ O.B. Tashirev, D-r Tech. Sci., S.O. Shilin, N.A. Chernaya \\ Institute of a microbiology and virology Nat. Acad. Sci. Ukraine, Kyiv, \\ e-mail: romanovskaya@serv.imv.kiev.ua
}

Search of methylotrophic bacteria has been carried out during time VII ${ }^{\text {th }}$ Ukranian Antarctic expedition (2003) at station «Academic Vernadsky». The psychrotolerant bacteria obligately using a methane have been found out in samples of mosses in an island part of Antarctic Region and in soil-plant samples. The quantity of methane oxidizing bacteria in samples from Antarctica $\left(10^{1}-10^{3} / \mathrm{g}\right.$ of the sample) was lower, than in samples from regions with a temperate climate $\left(10^{2}-10^{6} / \mathrm{g}\right.$ of the sample). The psychrotolerant bacteria of genus Methylobacterium facultatively using a methanol have been revealed in the silt of fresh and «Red» lakes, and also in soil-plant samples. Single psychrophilic strain which, probably is a new species of genus Methylobacterium was isolated at $10^{\circ} \mathrm{C}$ from soilplant sample of Antarctic Region. The majority of the collection mesophilic strains Methylobacterium isolated earlier from soils and plant phyllosphere from various regions of Ukraine is shown, that, also were capable to grow at $10^{\circ} \mathrm{C}$.

It was shown, that strains Methylobacterium are not catalysts of process of formation of ice. Moreover, some from them are capable to reduce temperature of freezing of water (process of crystallization of ice at their presence began at temperature lower- $13^{\circ} \mathrm{C}$ ), that is, naturally they have «antifreezing»effect on process of crystallization of ice. These properties of strains Methylobacterium may be very important in conditions of Antarctica for a survival both microbic, and plant forms.

As a whole, psychrotolerant facultative methylotrophs and the obligate methane oxidizing bacteria revealed by us in various ecosystems of Antarctic Region, expand representation about a physiological diversity of these groups of bacteria, about their distribution to biosphere and the contribution to a global cycle of carbon.

Психрофільні метилотрофні бактерії у біотопах Антарктики. В.О. Романовська, П.В. Рокитко, О.Б. Таширєв, С.О. Шилін, Н.А. Чорна

Під час VII Української антарктичної експедиции (2003р.) на станції «Академік Вернадський» психротолерантні бактерії, які облігатно використовують метан, було виявлено в різних екосистемах - у зразках мохів в острівній частині Антарктики та у грунтово-рослинних зразках. При цьому кількість метанокислюючих бактерій у зразках 3 Антарктики $\left(10^{1}-10^{3} / \Gamma\right.$ зразка) була нижчою, ніж у зразках із регіонів 3 помірним кліматом $\left(10^{2}-10^{6} /\right.$ г зразка). Психротолерантні бактерії роду Methylobacterium, що факультативно використовують метанол, було виявлено в мулі прісного й «Червоного» озер, а також у грунтово-рослинних зразках. 3 одного грунтово-рослинного зразка Антарктики при $10^{\circ} \mathrm{C}$ ізольовано психрофільний штам, що, можливо, є новим видом роду Methylobacterium.

Показано, що штами Methylobacterium не $є$ каталізаторами процесу льодоутворення. Більше того, деякі 3 них здатні знижувати температуру замерзання води (процес кристалізації льоду в їхній присутності починався при температурі нижче $-13^{\circ} \mathrm{C}$ ), тобто у природних умовах вони справляють «антифризну» дію на процес кристалізації льоду. Ці властивості штамів Methylobacterium можуть відігравати важливу роль в умовах Антарктики для виживання як мікробних, так і рослинних форм життя.

У цілому психротолерантні факультативні метилотрофи й облігатні метанокислюючі бактерії, виявлені нами в різних екосистемах Антарктики, розширюють уявлення про фізіологічну розмаїтість цих груп бактерій, про їхнє поширення в біосфері та їхній внесок у глобальний цикл вуглецю.

Психрофильные метилотрофные бактерии в биотопах Антарктики. В.А. Романовская,

Таширев, С.О. Шилин, Н.А. Черная

Во время VII Украинской антарктической экспедиции (2003 г.) на станции «Академик Вернадский» психротолерантные бактерии, облигатно использующие метан, были обнаружены в различных экосистемах - в образцах мхов в островной части Антарктики и в почвенно-растительных образцах. При этом количество метанокисляющих бактерий в образцах из Антарктики $\left(10^{1}-10^{3} / \Gamma\right.$ образца) было ниже, чем в образцах из регионов с умеренным климатом $\left(10^{2}-10^{6} / \Gamma\right.$ образца). Психротолерантные бактерии рода Methylobacterium, факультативно использующие метанол, были выявлены в донных отложениях пресного и «Красного» озер, а также в почвенно-растительных образцах. Из одного почвенно-растительного образца Антарктики при $10^{\circ} \mathrm{C}$ изолирован психрофильный штамм, который, возможно, является новым видом рода Methylobacterium.

Показано, что штаммы Methylobacterium не являются катализаторами процесса льдообразования. Более того, некоторые из них способны снижать температуру замерзания воды (процесс кристаллизации льда в их присутствии начинался при температуре ниже $-13^{\circ} \mathrm{C}$ ), т.е. в природных условиях они оказывают «антифризное» воздействие на процесс кристаллизации льда. Эти свойства штаммов Methylobacterium могут играть важную роль в условиях Антарктики для выживаемости как микробных, так и растительных форм жизни.

В целом психротолерантные факультативные метилотрофы и облигатные метанокисляющие бактерии, выявленные нами в различных экосистемах Антарктики, расширяют представление о физиологическом разнообразии этих групп бактерий, об их распространении в биосфере и вкладе в глобальный цикл углерода.

Methanotrophs and methanogens bring the essential contribution to a regulation of a metane cycle on the Earth. Nevertheless, concentration of a methane in an atmosphere annually increases for $1 \%$, obviously, as a result of a 
disbalance between its formation and decomposition. Comprehension of real threat of change of a climate during one or several centuries, as a result of pollution of biosphere, has induced ecologists and biogeochemists to engage in studying of a role of methanogens and methanotrophs in global processes of warming. Now the fact of preservation of viable microorganisms at constantly negative temperatures in the nature is authentically established. Microbiological and molecular-biological methods in eternally frozen sediments find out representatives of various phylogenetic lines: actinobacterias, endosporic bacteria, proteobacterias, etc. Not forming spores the Gram-positive bacteria concerning to order Actinomycetales dominate over frozen sedimentary breeds. Micromicetes and bacteria are found out practically in all investigated eternally frozen soils of Arctic and Antarctic regions of various genesis and age (from 5-10 thousand up to 2-3 million years). However practically there are no systematized researches concerning distribution of methylotrophic bacteria at low or negative temperatures.

Methylotrophic bacteria, that is the bacteria using for growth reduced one-carbon compounds are widely distributed in the nature. Traditionally among these bacteria distinguish two groups: obligate methanotrophs (the bacteria using only a methane or a methanol) and facultative methylotrophs (the bacteria using, alongside with methanol, other organic substrates). Until recently mesophilic and thermotolerant methane oxidizing bacteria were known only. Studying of methanotrophs of psychrosphere under the general management of the academician of the Russian Academy of Science G.A.Zavarzina have led to an isolation from a tundra soil of first psychrophilic methanotroph Methylobacter psychrophilus [1] which has been found out in Arctic tundra where the methanotrophic bacterial community occupies the certain soil horizons, from pollen of a moss up to peat [2]. The new species of psychrophilic methane oxidizing bacteria is described also: Methylosphaera hansonii which is isolated from meromectical salty lake in Antarctica Region [3].

The purpose of our work - search of psychrophilic and psychrotolerant methylotrophic bacteria in extreme biotopes of Antarctic Region.

\section{Methods}

The quantitative account of methane oxidizing bacteria and facultative methylotrophic bacteria was performed making a spreading of consequent tenfold dilutions of soil-plant and other samples on agarized mineral media (used agar Difco).

For revealing obligate methane oxidizing bacteria used medium K [4] (a source of carbon feed - methane, $50 \%$ in a gas mixture), for revealing pink pigmented facultative methylotrophs used medium MM [5] (a source of a carbon feed - a methanol, 0,5 mol. \%).

Cultivation carried out at temperature $10^{\circ} \mathrm{C}$ and $20^{\circ} \mathrm{C}$ during $5-10$ day. Then separate colonies of methane oxidizing bacteria disseminated on plates with an agarized medium K [4] and placed in a methane-air atmosphere. As the control similar crops on complex organic mediums served. Absence of growth on these mediums testified to bacteriological cleanliness of isolated bacteria. Pure cultures of facultative methylotrophs isolated, using standard procedures.

Isolation cellular DNA, amplification of sequences of a gene 16S rRNA with use of oligonucleotide primers (27f and 1492r) performed the methods described earlier [6]. PCR performed on thermal cycler Gene Amp PCR System 2400 (Perkin Elmer), using a standard set of reagents (DTCS Master Mix) which is given to material maintenance of Beckman Coulter CEQ ${ }^{\mathrm{TM}}$ 2000XL DNA analysis system.

\section{Results}

During time VII ${ }^{\text {th }}$ expedition (2003) samples from Antarctic Region have been taken on islands Galindez, Pitterman, Scua and near station «Academician Vernadsky» from various ecosystems: a soil, silt of fresh shallow lakes, an alga film on rocks in zone of ocean inflow, the bird's excrement, a moss, ground sediments of ocean.

Psychrotolerant methane oxidizing bacteria have been found out in samples of the mosses selected in an island part of Antarctic Region and in soil-plant samples (Table 1). In some samples (ocean silt, alga film at ocean) psychrotolerant methane oxidizing bacteria have not been revealed. The highest quantity of methanotrophs is revealed in places of anthropogenous pollution in area of station Academician Vernadsky. As a whole the quantity of methane oxidizing bacteria in ecosystems of Antarctic Region $\left(10^{1}-10^{3} / \mathrm{g}\right.$ of a sample) was lower, than in regions with a temperate climate $\left(10^{2}-10^{6} / \mathrm{g}\right.$ of a sample [7]).

Nevertheless, revealing of methane oxidizing bacteria in ecosystems of Antarctic Region is the valuable fact as these bacteria are one of part which provide circulation of carbon in biosphere. Moreover, methane oxidizing bacteria it is unique physiological group of bacteria which utilize a methane. Therefore they prevent accumulation of a methane in an atmosphere.

Psychrotolerant methanol utilizing bacteria have been revealed in the silt of fresh and «Red» lakes, and also in soilplant samples. They have been presented by the pink pigmented bacteria facultatively using as a methanol, and others carbon containing compounds as a unique source of a carbon feed, and attributed to genus Methylobacterium. From one soil-plant sample of Antarctic Region at $10^{\circ} \mathrm{C}$ was isolated the psychrophilic representative of genus Methylobacterium. Now it is known about 20 species of genus Methylobacterium, all of them are the mesophils growing at $25^{\circ} \mathrm{C}-30^{\circ} \mathrm{C}$. Psychrophilic strain Methylobacterium (An-5) was revealed for the first time.

The comparative analysis of sequences of genes 16S rRNA strain An-5 with those sequences of various species of bacteria in database GenBank, carried out with the help of program BLASTN 2.2.4, has shown, that it relate to class Alphaproteobacteria, in particular, to genus Methylobacterium. The highest factor of similarity of strain An-5 has been 
obtained with species Methylobacterium mesophilicum (95,2 \%). With other species of genus Methylobacterium this strain had lower level of similarity - 92-95\% that has not allowed to relate it to known species Methylobacterium. Isolated psychrophilic strain An-5, probably, is a new species of genus Methylobacterium.

Quantity of methylotrophic bacteria in the samples wich was selected in Antarctic Region (2003)

\begin{tabular}{|l|l|c|c|}
\hline \multicolumn{2}{|c|}{ Characterization of the sample } & \multicolumn{1}{c|}{ Colony quantity / $\mathrm{g}$ of the sample } \\
\hline Region & \multicolumn{1}{|c|}{ Ecosystem } & $*$ Methylotrophs & $*$ Methanotrophs \\
\hline $\begin{array}{l}\text { UAS "Academician } \\
\text { Vernadsky" }\end{array}$ & A moss with a soil & 0 & $3,6 \times 10^{2}$ \\
\hline Isl. Mario-Pedra, Greenwich & Soil & $3,0 \times 10^{2}$ & $\mathrm{nd}$ \\
\hline \multirow{2}{*}{ Isl. Galindes } & Silt of fresh lake & $1,8 \times 10^{2}$ & $\mathrm{nd}$ \\
\cline { 2 - 4 } & Dry moss & 0 & $2 \times 10^{2}$ \\
\cline { 2 - 4 } & Grass with a soil & $3,8 \times 10^{2}$ & $1,2 \times 10^{2}$ \\
\hline Isl. Irizar & Soil & $9,0 \times 10^{2}$ & $\mathrm{nd}$ \\
\hline \multirow{3}{*}{ Isl. Pitterman } & Moss on the excrements & $2,0 \times 10^{2}$ & $3,5 \times 10^{2}$ \\
\cline { 2 - 4 } & Moss on the rock & 0 & $\mathrm{nd}$ \\
\cline { 2 - 4 } & Silt of the Red Lake & $6,0 \times 10^{2}$ & $\mathrm{nd}$ \\
\hline Isl. Scua & Alga film at ocean & 0 & 0 \\
\hline Isl. Barhany & Moss, soil, wool of seals & $3,0 \times 10^{2}$ & $\mathrm{nd}$ \\
\hline $\begin{array}{l}\text { Isl. King Georg, } \\
\text { Rus. St. Bellinsgauzen }\end{array}$ & $\begin{array}{l}\text { Pink lichen on stones and } \\
\text { soil }\end{array}$ & $7,0 \times 10^{2}$ & $\mathrm{nd}$ \\
\hline
\end{tabular}

*Methylotrophs - pink pigmented facultative methanol utilizing bacteria of genus Methylobacterium. Methanotrophs obligate methane oxidizing bacteria.

nd -. did not determine.

In connection with obtained results the temperature range of growth of the facultative methylotrophs collection strains isolated by us earlier from soils and plant phyllosphere of various regions of Ukraine has been tested (Table 2). It turned out, that the majority of strains Methylobacterium are capable to grow at $10^{\circ} \mathrm{C}$. However, if at $30^{\circ} \mathrm{C}$ the maximal biomass gain was observed after 2 day, at $10^{\circ} \mathrm{C}$ after $2-3$ day growth is absent, and the maximal gain of a biomass was observed only after 5 day. Thus, the long lag-phase at low temperatures is observed, during which, probably, the metabolism of a cell is reconstructed. Finally, the gain of a biomass at $10^{\circ} \mathrm{C}$ for $48-72 \mathrm{~h}$ growth reaches the same level, as at $30^{\circ} \mathrm{C}$.

Growth of the Methylobacterium collection strains at various temperature

Table 2

\begin{tabular}{|c|c|c|c|c|c|c|}
\hline \multirow{4}{*}{ Species } & \multirow{4}{*}{$\begin{array}{c}\text { Strain } \\
\text { number in } \\
\text { UCM }\end{array}$} & \multicolumn{5}{|c|}{ Temperature of cultivation } \\
\hline & & $10^{\circ} \mathrm{C}$ & $20^{\circ} \mathrm{C}$ & $30^{\circ} \mathrm{C}$ & $37^{\circ} \mathrm{C}$ & $42^{\circ} \mathrm{C}$ \\
\hline & & \multicolumn{5}{|c|}{ During cultivation, day } \\
\hline & & 5 & 5 & 2 & 5 & 5 \\
\hline M. mesophilicum & 3352 & + & ++ & ++ & ++ & - \\
\hline M. mesophilicum & 3354 & + & ++ & ++ & - & - \\
\hline M. mesophilicum & 3357 & + & ++ & + & + & - \\
\hline M. mesophilicum & 3380 & + & ++ & ++ & ++ & - \\
\hline M. mesophilicum & 3383 & + & + & + & - & - \\
\hline M. fujisawaense & 3342 & + & + & + & + & + \\
\hline M. fujisawaense & 3351 & ++ & ++ & ++ & - & - \\
\hline M. fujisawaense & 3365 & + & + & ++ & - & - \\
\hline M. extorquens & 3360 & + & + & ++ & - & - \\
\hline M. extorquens & 3362 & - & ++ & ++ & - & - \\
\hline M. extorquens & 3368 & ++ & ++ & + & - & - \\
\hline M. zatmanii & 3339 & - & ++ & ++ & ++ & ++ \\
\hline M. organophilum & 3389 & ++ & ++ & ++ & - & - \\
\hline
\end{tabular}

Note: "++" - normal growth; "+" - weak growth; "-" - absence of growth:

UCM - Ukrainian collection of microorganisms.

Whether methylotrophic bacteria a aboriginal microflora in Antarctic Region are? On this question there is no unequivocal answer. It is possible, that they have an anthropogenous origin or are introduced by birds. However among representatives of methylotrophic bacteria psychrophilic and psychrotolerant forms are revealed. It testifies to a potential opportunity of these bacteria to exist at low temperatures. Moreover psychrotolerant forms of methylotrophs are found out also among mesophilic collection bacteria which have been isolated from ecosystems with a temperate climate.

Nevertheless, objective conditions for their existence are available in the given region. So, natural processes of transformation of organic substances (a moss, the bird's excrement, etc.) up to a methanol and a methane can provide trophic needs of methylotrophs and their ability exist at low temperatures can to be realized in conditions of Antarctic Region. Recycling by methylotrophs of a methane and a methanol in ecosystems of Antarctic Region, undoubtedly, has the important ecological value as protects an atmosphere from pollution by these toxic compounds. 
Earlier by us it has been shown, that epiphitic and soil strains Methylobacterium extorquens, M. organophillum, M. mesophilicum, M. fujisawaense are not catalysts of process of ice formation. Moreover, some from them are capable to reduce temperature of water freezing (process of ice crystallization at their presence began at temperature lower $-13^{\circ} \mathrm{C}$ ), i.e., naturally they have an «antifreezing» effect on process of ice crystallization [8]. These properties of strains Methylobacterium may be very important in conditions of Antarctic Region for a survival both microbic, and plant forms.

As a whole, psychrotolerant facultative methylotrophs and the obligate methane oxidizing bacteria revealed by us in various ecosystems of Antarctic Region, expand knowledge about a physiological diversity of these groups of bacteria, about their distribution into biosphere and the contribution to a global cycle of carbon.

\section{References}

1. Tourova T.P., Omel'chenko M.V., Fegeding K.V., Vasiljeva L.V. Phylogenetic position of Methylobacter psychrophilus sp. nov // Mikrobiology. - 1999. - 68, № 4. - P. 568-570 (in Russian).

2. Berestovskaya Yu.Yu., Vasil'eva L.V, Chestnykh O.V., Zavarzin G.A. Methanotrophs of the Psychrophilic Microbial Community of the Russian Arctic Tundra // Mikrobiology. - 2002. - 71, № 4. - P. 460-471 (in Russian).

3. Bowman,J.P., McCammon S.A., Skerratt J.H. Methylosphaera hansonii gen. nov., sp. nov., a psychrophilic, group I methanotroph from Antarctic marine-salinity, meromictic lakes // Microbiology. - 1997. - 143, № 4. - P. 1451-1459.

4. Romanovskaya V.A., Stolyar S.M., Malashenko Yu. R.. A systematics of methylotrophic bacteria. - Kyiv: Naukova dumka, 1991. - 211 p. (in Russian).

5. Romanovskaya V.A., Stolyar S.M., Malashenko Yu.R. Occurrence of bacteria of genus Methylobacterium in various ecosystems of Ukraine // Mikrobiologichny zhurnal. - 1996. - 58, № 3. - P. 3-11 (in Russian).

6. Romanovskaya V.A., Rokitko P.V., Shilin S.O., Malashenko Yu.R. Identification of strains Methylobacterium with use of the sequence-analysis of gene 16S rRNA // Mikrobiology. - 2004. - 73, № 6. - P. 846-848 (in Russian).

7. Malashenko Yu.R. Hiyer Yu, V.A. Romanovskaja, Muchnik F.V. Biology of methane forming and methane oxidizing bacteria. Kyiv: Naukova dumka, 1993. - 257 p. (in Russian).

8. Romanovskaya V.A., Stolyar S.M., Malashenko Yu.R., Dodatko T.V. Way of colonization of plants by strains Methylobacterium and their some properties // Mikrobiology. - 2001 - - 70, № 2. - P. 263-269 (in Russian). 